\title{
Sub-Rosa Selling as a Settlement of Nonperforming Loans Tied to Credit Agreement with Fiduciary Guarantee in PT. Bank Rakyat Indonesia (Limited) Ltd.
}

\author{
Shinta Putri Pradita*; M. Hudi Asrori S. \\ Universitas Sebelas Maret, Indonesia \\ Email: shinta.praditta@ymail.com
}

http://dx.doi.org/10.18415/ijmmu.v5i4.417

\begin{abstract}
This research purpose is to acknowledge problems upon the Warranty Law, especially upon the completion process of the troubled credit upon Sub-Rosa selling with Fiduciary warranty of PT. Bank Rakyat Indonesia (Limited) Ltd. and the risen obstacles upon the troubled credit completion under subRosa with Fiduciary warranty of the PT. Bank Rakyat Indonesia (Limited) Ltd. The research was completed in PT. Bank Rakyat Indonesia (limited) Ltd. with the research subject including Account Officer (AO) of the bank. The research methodology used was Juridical Empirical, which used the fact approach system by executing observation and research on the field, which then evaluated and examined based upon the related regulation. The data used was primary data, which was taken directly from the field by using questioner and interview, and secondary data, which was literature. The data analysis used was analytical Qualitative with deductive concluding. The research results are: 1) Based upon the result, upon the completion of troubled credit if the fiduciary provider was not responsible, BRI executed subRosa selling by asking the debtor to sell the warranty willingly, then gave the result to the bank to complete the loan. The method was considered faster, more effective, and efficient than the method of court settlement; 2) Upon the completion of the troubled credit by using sub-Rosa selling instrument, there were obstacles that delayed the completion.
\end{abstract}

Keywords: Loan Agreement; Fiduciary Warranty

\section{Introduction}

PT. Bank Rakyat Indonesia as one of the Government's General Bank, one of its activities is to gather funds from the public and then channel it back to the community in the various forms of credit, which is a type of financing in common. The activities of credit disbursed, contain risks that may affect the health and livelihoods of bank business. Likuditas financial solvency and profitability of the bank, was heavily influenced by their success in managing credit is channelled. Most banks are bankrupt or facing an acute financial difficulties, due to the entangled cases of nonperforming loans in large numbers.

The implementation of the granting of credit is generally done by having an agreement. The agreement consists of the principal Treaty, namely the Treaty of debts and followed by additional agreements in the form of the granting of the guarantee agreement by the debtor. Generally known there 
are 2 (two) form of guarantee, i.e. a guarantee of individuals and material warranty. In practice, the most frequently used guarantee is a guarantee of material, one of which is the guarantee of the Fiduciary. The guarantee institution is the institution of guarantees over moving objects and many have been used by people in the business.

Prior to the enactment of Act No. 42 of the year 1999 about Fiduciary Guarantee, the difficulties faced by the bank in terms of execution, since there is no clarity settings. So in the implementation of their execution procedure is performed with a lawsuit to the Court, which usually take time and cost a lot more. However, with the enactment of Act No. 42 of the year 1999 about Fiduciary, fiduciary guarantee execution then the process is made easier by the existence of several options for the bank in the implementation of their execution which are enshrined in article 29 paragraph (1) are: ${ }^{1}$

(1) when the the debtor or the giver of Fiduciary appointments to injuries, the execution of objects which become objects of Fiduciary Guarantee can be done by means of:

a. implementation of the title eksekutorial as stipulated in article 15 paragraph (2) by the Fiduciary;

b. the sale of objects into objects of the powers of Fiduciary guarantee of the Fiduciary's own Receivers through public auctions as well as take full piutangnya of the proceeds;

c. sub-Rosa selling is done based on the agreement of Fiduciary if the giver and receiver in this way can be obtained the highest price that benefits all parties.

In the settlement of bad debts in Bank Rakyat Indonesia PT. Surakarta Branch of the object fidusianya guarantees, mostly using the execution under the hand. Nevertheless, surely the execution under the hand also has weaknesses in its implementation. Starting from the blurb dotted on top, then a writer interested in researching more about the problems and set them out in the article entitled "sub-Rosa selling AS a SETTLEMENT of NONPERFORMING LOANS TIED to CREDIT AGREEMENT With FIDUCIARY GUARANTEE in PT. Bank Rakyat Indonesia (Limited) Ltd".

\section{Methodology}

Research methodology used in this study is the Empirical juridical, empirical juridical Research done by researching in the field by means of interviews with the respondents that are the primary data and examine the materials library secondary data and is also called the research libraries. ${ }^{2}$ The data used is primary data, namely data obtained directly from the field using a detailed questionnaire and interviews, as well as secondary data which consists of the study of librarianship. ${ }^{3}$ Data analysis qualitative analysis used was the withdrawal of the conclusion are deductive.

\section{Problems}

How the implementation of the resolution of bad debts via execution of sub-Rosa sellings of the fiduciary guarantee objects on PT Bank Rakyat Indonesia (Limited)?

\footnotetext{
${ }^{1}$ Act No. 42 of the year 1999 about Fiduciary.

${ }^{2}$ Sutrisno Hadi, Metodologi Riset Nasional. (Jakarta: Rineka Cipta, 2001), page. 46.

${ }^{3}$ Ronny Hanitijo Soemitro, Metodologi Penelitian Hukum, (Jakarta: Ghalia Indonesia, 1985), page 24.
} 


\section{Results and Discussion}

PT Bank Rakyat Indonesia Ltd or abbreviated BRI, is one of the perpetrators of the economic activity in the world's economy. Standing on 16 December 1895, which then serve as the birth day of PT Bank Rakyat Indonesia (Limited) Ltd. Founder of Bank Rakyat Indonesia, Raden Aria Wirjaatmadja in the period after the independence of Indonesia, based on Government Regulation No. 1 year 1946 article 1 stated that the people's Bank of Indonesia as the first Government Bank in the Republic of Indonesia. ${ }^{4}$

In carrying out its functions as a financial intermediary institutions, so that its operational activities in the implementation of what has been achieved is targeted, the following is the vision and mission of PT. Bank Rakyat Indonesia (Limited) Ltd are:

1. The vision of PT. Bank Rakyat Indonesia (Limited) Ltd. To become a leading commercial banks always give priority to the satisfaction of the customer.

2. The Mission of the people's Bank of Indonesia PT. (Limited) Ltd with)

a) Do the best banking activities with emphasis on services to micro, small and medium enterprises in order to support the improvement of the economy of the community.

b) Provide excellent service to customers through a network of widespread and supported by human resources professionals by implementing good corporate governance practices.

c) Provide optimal benefits and advantages to the parties concerned.

One of the activities of the BRI is funneling credit. Hasanuddin Rahman argued the four elements of the credit as follows: 1) trust, that any granting credit is based on the belief that bank credit by that will be paid back by the debtor in accordance with the time period already exchanged; 2) time, that between the granting of credit by the bank with payment by the debtor is not done at the same time, but are separated by a period; 3) risk, that any credit granting any type of risk will be contained within the period between the granting of credit and repayment. This means the more lengthy period of credit, higher credit risk; 4) achievements, that any agreement between the bank and the debtor regarding the granting of credit, then at that time also will happen an accomplishment and cons achievement. ${ }^{5}$

The granting of loans with guarantee of the fiduciary on the BRI Branch Surakarta aims to help communities that need the funds for working capital, with the funds expected community can develop its business. Credit basis is trust where a person who obtained the credit means he obtained the trust and the person or legal entity in the sense of giving credit is based on the belief in the existence of credit recipients in the future will be able to meet everything that has been exchanged. The mechanism of granting credit with the assurance of a fiduciary is done by holding the principle of prudence, the granting of loans with guarantee of this more to the fiduciary trust factor, bonafiditas and prospects of the debtor's business activities. Given the importance of the position of the Fund is of course if the giver and receiver of credit as well as other relevant parties got protection through a strong guarantee of the rights and provide legal certainty for the parties interested parties.

Credit guarantee serves as security upon repayment of the credit. In terms of legislation is defined, that banks were forbidden to give credit without collateral. Although in the banking law does not

\footnotetext{
${ }^{4}$ http://www.bumn-swasta.web.id/2015/12/pt-bank-rakyat-indonesia-persero-tbk.html. accesed on 1 Juli 2018 at 09.28 a.m.

${ }^{5}$ Hasanuddin Rahman, Aspek-aspek Hukum Pemberian Kredit Perbankan di Indonesia, Citra Aditya Bakti, Bandung. (1995). page 25.
} 
require the granting of credit must be accompanied by guarantees, but in practice the bank insisted the guarantee of the credit applicant, besides doing the analysis of good faith and the circumstances business credit application. Credit guarantees are guarantees of material, which can be either fixed or moving objects are objects whose value is sufficient to guarantee credit. Credit guarantee bank acceptable collateral material in General is good, keep the object encumbered with rights to dependents or moving objects that are warranted in fiduciary relationships. Fiduciary guarantee submission is done based on belief (constitutum possessorium), so that the debtor to the creditor is not his, but the right of ownership, thus the fiduciary guarantee objects are still in the power of the debtor. This is in accordance with the provisions of article 1 of the Act Number 42 Year 1999 about Fiduciary Guarantee which States:

"A fiduciary is a transfer of the possession of an object on the basis of trust on the condition that the rights of ownership of objects that remain in the mastery of the diverted the owner of objects".

Based on the research results, the magnitude of the value of the object of the guarantee credit of at least $150 \%$ of the large credit score requested by the customer. The object of the guarantee may be accepted as security for bank credit is fixed objects and moving objects. Fixed objects that received the bank is in the form of land and buildings that is a property or building use rights tied with dependents. For moving objects, the objects bound by fiduciary guarantee. According to the Account Officer (AO) BRI Branch of Surakarta, that in providing credit, maximum credit can be given bank is of $80 \%$ of the value of the auction Price Estimates of Sita (THLS) on the object of the guarantee. In practice, the BRI Branch of Surakarta only give credit of a maximum of $50 \%$ of the value (THLS) for fiduciary guarantee. ${ }^{6}$

According to the law, the fiduciary guarantee is considered born after fiduciary guarantee were chronicled into list of Fiduciary. Next Registration Office will issue a certificate of Fiduciary Fiduciary Guarantee and given to those who register a Fiduciary guarantee. The Fiduciary Guarantee certificate contains the preferred rights for the holder, i.e. the right to preferred compliance piutangnya from the sale of the fiduciary guarantee object from another lender. The imposition of a fiduciary guarantee did not follow the provisions of the Act, do not get the protection of the law. The position of the recipient of the fiduciary in this case not as a preferred lender, while the giver of the fiduciary also do not get the protection of the law as stated in article 4 jo Article 25 Law Number 42 Year 1999 About Fiduciary Guarantee.

Based on the results of research, BRI Branch of Surakarta is also following the imposition and registration procedure against a fiduciary guarantee of the object, as described above. The position of the BRI as the holder of the guarantee is constructed as fiduciary owner juridical over fiduciary guarantee of the objects, while the debtor is constructed as an owner economically upon the fiduciary guarantee of the object, in the sense that the debtor giver fiduciary remains controlled and may benefit from the guarantee of these fiduciary objects including divert or sell, on the condition that a guarantee has been object against redirected should be replaced with an equivalent value. This is in accordance with the provisions stated in article 20 and article 21 of Act No. 42 of the year 1999 about Fiduciary Guarantee. In the event the debtor giver fiduciary appointments to injuries then BRI Branch based on the Fiduciary Guarantee Certificate of Surakarta, serves as the preferred creditors are entitled to repayment of preferred piutangnya of the proceeds of such fiduciary guarantee object.

In the activity of granting credit, BRI Surakarta Branch cling to the principle of prudence. It can be seen from various preventative measures are applied during the process of granting credit, starting from the initial submission of credit procedures, assessment of the credibility of the applicant's credit, assessment of business activities that will be financed with the credit, and assessment of credit guarantees, checking of data, and do the testing against the validity of all data obtained from the results of the analysis of the feasibility of potential debtors. BRI Surakarta Branch also monitors the use of credit, credit

\footnotetext{
${ }^{6}$ Andi Mukti Santoso, Interview, Account Officer (AO) PT. Bank Rakyat Indonesria (Limited) Surakarta, on 26 June 2018.
} 
installment payment activities and the presence of objects the object inventory assurance fidusianya. However it cannot guarantee that the debtor remains committed to doing every mortgage payment due date specified by the debtor itself in credit agreements.

From the results of the study found some causes of the occurrence of the credit arrears resulted in bad debt, namely: 1) The internal factors of the bank. The lack of validity of the bank's analysis of the condition of the debtor and the lack of prudential principles in providing credit can be the cause of problem loans, such as the expansive credit policy deviating from the system and procedures, the weakness of the administration system and the supervision of the distributed credit; 2) Inhibition of debtor business activities. There is a condition in which the debtor business is in a difficult situation, the debtor's business production is decreasing due to the difficulty of obtaining raw materials of production, or being inadequate market demand resulting in a lack of sales of products that impact on the financial condition of the debtor; 3) Deviation of credit usage. Loans granted are not used by the debtor in accordance with the purpose of crediting. The use of credit is transferred either partly or wholly for other purposes beyond the purpose of crediting; 4) The existence of bad faith from the debtor. The Borrower intentionally refuses to pay the credit installment and or the debtor intentionally does not replace the inventory of the transferred fiduciary asset object with an equivalent object in accordance with the provisions of Article 21 paragraph (3) of Law Number 42 Year 1999 concerning Fiduciary Security.

Based on the results of the research known that the handling of problem loans conducted BRI Branch of Surakarta in various ways and shapes, depending on the faith and the business state of the debtor. There are two ways of completion:

\section{a) Through Negotiation}

Negotiations, conducted against debtors who have good faith, cooperative and business activities can still be saved. This negotiation in practice is manifested in the form of problem loans restructuring. Negotiations are used as a first step to resolve non-performing loans.

\section{b) Through Execution}

The execution, carried out after the settlement through negotiation by means of restructuring is not successful. Execution is an act with the purpose of selling the collateral object for debt repayment debt. The execution of a fiduciary security object may be made through the State Receivable and Auction Service Office or under Article 29 of Law Number 42 Year 1999 concerning Fiduciary Security.

Based on the results of research, the steps taken by BRI Branch of Surakarta in an effort to handle credit arrears as the cause of problem loans are:

\section{Notification of Late Payment}

Notification of late payment of credit installment is made 1 (one) day after credit payment due date. One day after the due date of payment of credit installment, if the debtor has not made installment payment, will report late payment of payment from computer credit admin on behalf of the debtor. This late payment report will be submitted by the credit admin to the marketing department, which will then be followed up with this late notice to the debtor by phone and late notice. Mail notifications are done once a month. Telephone notifications are made once a week for a month starting from the day of late payment. After exceeding the first one-month grace period the debtor has not shown goodwill or uncooperative, the 
bank will issue a letter of warning that is harder than the notice. This letter of reprimand is usually accompanied by the presence of the bank to the debtor to request a statement of ability to pay credit installments. This is done during the second month, with a one-week arrival time in a week. At this stage the bank still open the settlement based on the principle of deliberation and kinship, but the bank will provide a note on the credit regsiter of credit in the form of creditors to creditor status in a special supervision.

\section{Provide a Warning Letter}

However, if it has been past one month from the letter of reprimand, the debtor has not shown good faith and does not cooperatively settle its obligation to pay the credit, BRI Branch of Surakarta will send a warning letter or (SP) to the debtor. This warning letter is included in the category of violent warning, with the issuance of this warning letter then the bank will lower the credit status of the debtor. This warning letter is given three times over three weeks by: ${ }^{7}$

a. The Bank will issue the first warning letter (SP-1) to the debtor, with the issuance of this SP-1, the debtor's credit status will be derived from the credit in special attention, to be less or less smoothly. At this stage the bank starts to take action that is preventive to the debtor, especially with respect to the object of credit guarantee. This is understandable because the object of credit guarantees is fiduciary of inventory, meaning the existence and mastery of objects economically still on the debtor. The Bank shall exercise closer inspection and scrutiny of the flow of the sale and replacement of such security items. This is done to minimize the risk of possible bad faith of the debtor over the transfer of the object or to the result of the transfer of the fiduciary security object. The risk may be the nonreplacement of a fiduciary asset with an object of equivalent value, or it may be a transfer of proceeds from the sale of the fiduciary guarantee goods, which would be detrimental to the bank as a lender.

b. One week after sending SP-1 there is also no sign of goodwill from debtors to settle their obligations, the bank will issue SP-2. The granting of SP-2 caused the bank to lower the debtor's status from nonperforming loans to doubtful credit.

c. Grace period one week after the SP-2 is sent and the debtor has not responded with cooperative attitude, then the bank will issue SP-3. With the issuance of SP-3, the bank will lower the debtor's credit status from the doubtful credit to bad credit. By granting bad credit status to the client register, the bank will take security measures against assets that become credit guarantees. Because in this case the credit guarantees are fiduciary of inventory, where the object is indeed to be traded, then the action taken by the bank is to ask the debtor to stop the whole transaction of transfer/ sale of the fiduciary guarantee object.

This bank request is more to the appeal of its nature, because there is no guarantee that the debtor will comply. In addition, in accordance with the provisions of Article 21 paragraph (4) of Law 42 Year 1999 concerning Fiduciary Guaranty, the proceeds of the transfer or invoices arising from the transfer by law shall be the object of replacement fiduciary warranties of the transferred fiduciary object. The Bank will also request that all billing receipts, and the transfer/ sale of the collateral as a substitute fiduciary security object, at this stage is in fact the weakness of the fiduciary guarantee. In this case, for the naughty debtor it would be easy to commit fraud against such fiduciary goods, such as the sale and proceeds of the sale being transferred to another business. In this case the bank's position is weak against the collateral goods and the lack of legal certainty obtained by the bank for the return of credit that has been disbursed, because the object of the guarantee is no longer existed.

\footnotetext{
${ }^{7}$ Andi Mukti Santoso, Interview, Account Officer (AO) PT. Bank Rakyat Indonesria (Limited) Surakarta, on 26 June 2018.
} 
Thus, banks are actually reluctant to accept fiduciary collateral as an object of credit guarantees, even if the bank receives, it is more than just respecting the law alone. Therefore, for fiduciary secured loans, the bank will apply strict conditions, the credit is relatively small, and for large credit applications, the bank will ask for a guarantee other than this fiduciary guarantee. At this stage of SP-3 the bank also opens opportunities for debtors who have good faith to complete their credit payments.

\section{Somation Through District Court}

Somasi through the District Court, conducted BRI Surakarta Branch as an effort to get stronger support from legal institutions, in an effort to return the credit that has been disbursed. It is not an obligation for a government bank. This is similar to a warning letter, but it is done by using the power of judges. This through court verdict is actually done as one way to "frighten" debtors into fulfilling their obligations to pay credit. In this case, the application of the summon is filed by BRI Surakarta Branch in writing to the District Court whose jurisdiction covers the domicile of the debtor or domicile law which has been chosen according to the credit agreement. The application is accompanied by a copy of the credit agreement file, and the proof of granting SP-1 up to SP-3 by the bank to the debtor. In this case the judge will give the debtor a maximum of 3 (three) times. Within each grace period the judge will provide the debtor with the opportunity to settle the matter in a kinship manner and try to reconcile the bank with the debtor.

However, if the debtor has been granted 3 (three) times by the judge remains uncooperative, or no settlement agreement is reached between the bank and the creditor, the court will subsequently establish the confiscation of the fiduciary guarantee object and will be subsequently submitted by the District Court to the Service Office State Assets and Auctions for auction in accordance with the mandate of Law No. 49 Prp Year 1960 dated 14 December 1960 on State Receivables Management Committee, whose technical implementation and administration are regulated in the decree. TELLING. No. 304 / KMK.01 / 2002 and SK.DJPLN No. 35 / PL / 2002 joncto No. 6838 / PL / 2002. The auction result, after deducting the cost of the auction and other deductions, will be used for loan repayment. If there is a remainder of the auction proceeds after deducting the credit repayment, the excess will be returned to the debtor.

Nonperforming loans are a very likely risk of credit lending and are a symptom that every bank should watch out for as a lender. According to Decree of the Board of Managing Directors of Bank Indonesia Number 31/147 / DIR dated November 12, 1998 regarding Earning Asset Quality, which belongs to the Non Performing Loan (NPL) category, are credits in the category of substandard, doubtful credit and non-performing loans. ${ }^{8}$

Non-performing loans are generally due to credit arrears, since the debtor can not perform its obligations to pay credit installments, just in time as agreed in the credit agreement. In the credit granting mechanism, the bank must have confidence that the credit given can be returned in accordance with the contract. For that the bank must adhere to the principle of prudence in giving credit. The Bank shall conduct an in-depth analysis of the borrowers of potential borrowers. The analysis concerns the business activities of the debtor, the business prospects of the debtor, as well as the credit guarantee given by the debtor. This precautionary principle is in accordance with the provisions of Article 8 of Law no. 7 of 1992 concerning Banking which affirms that:

"In the provision of credit, commercial banks must have confidence in the ability and ability of the debtor to repay the debt in accordance with the contract."

\footnotetext{
${ }^{8}$ Decree of the Board of Managing Directors of Bank Indonesia Number 31/147 / DIR concerning Earning Assets Quality.
} 
The principle of prudence in the provision of credit is manifested in the form of feasibility analysis of prospective borrowers receiving credit. This analysis is conducted in depth, related to the principle of $5 \mathrm{C}$, which is the analysis of personality (character), analysis of capacity, capital analysis, economic condition analysis, collateral credit analysis) of the prospective debtor. ${ }^{9}$

The feasibility analysis of the debtor candidate is conducted to provide confidence to the bank for the security of credit to be provided. The analysis of collateral or credit guarantee to be provided by debtor candidate is one part of credit security measures, because as the function of the guarantee object is to guarantee the certainty of credit repayment. The prudential principles shown by banks in the crediting also refer to the provisions of Article 29 paragraph (4) of Act Number 7 of 1992 concerning Banking which states that: ${ }^{10}$

"For the interest of the customer, the bank is required to provide information concerning the possibility of any risk of loss in connection with customer transactions conducted through the bank."

If, according to the bank's consideration, the problem loan is unlikely to be rescued to become smooth again through rescue efforts as described above and finally the credit in question becomes bad credit, the bank will take settlement or collection actions against the credit. Based on the result of the research in settling the bad credit if the fiduciary donor is injured, the BRI branch of Surakarta bank conducts the sale under the hand by requesting to the debtor to make its own voluntary sales voluntarily, for subsequently the result is submitted to the bank to pay off the credit. ${ }^{11}$

Based on this article, in practice the bank is given the ease to carry out its own execution on the basis of its power. According to the bank, with the existence of this article, the bank is facilitated in solving the problem loans, especially fiduciary guarantee, because the legal procedure is shortened. This is because if the bank uses a settlement through a public tender (parate execution), then the procedure is quite long and uses a large cost even though the law has provided a strong legal basis for execution of collateral based on execution parate, but in terms of implementation The Auction Office is not willing to conduct an auction based on the execution parate.

In the process of credit engagement guaranteed by the moving object is bound by fiduciary as set forth in Law No. 42 on Fiduciary Guarantee Article 1 of this law gives the understanding that fiduciary is the transfer of ownership of an object on the basis of the belief in which the right of ownership of the object remains in control of the owner of the object. The nature of the fiduciary guarantee as stipulated in Article 1 paragraph 2 of the Fiduciary Guaranty Act states that: ${ }^{12}$

"Fiduciary Guaranty is the right of guarantee of tangible and intangible moving objects, especially immobilized buildings, which can not be burdened with the Deposit Rights as referred to in Law Number 4 of 1996 concerning the Right of Dependent which is in the Fiduciary Giver's satisfaction, as collateral for certain debt repayment, which gives priority to the Fiduciary Receiver to other creditors ".

This means that the Fiduciary Guarantee Act expressly states that the Fiduciary Guarantee is a collateral for material or security guarantee (zakelijke zekerheid) which gives priority to the Fiduciary Receiver. As the principle of material assurance in which the auction is established in order to guarantee a certain debt agreed upon in the credit agreement (as the principal agreement), the Fiduciary Guarantee

\footnotetext{
${ }^{9}$ Habib Adjie, Hak Tanggungan sebagai Lembaga Jaminan Atas Tanah, Mandar Maju, Bandung. (2000). page. 1.

${ }^{10}$ Law Number 7 of 1992 amended by Act Number 10 of 1998 concerning Banking.

${ }^{11}$ Andi Mukti Santoso, Interview, Account Officer (AO) PT. Bank Rakyat Indonesria (Limited) Surakarta, on 26 June 2018.

${ }^{12}$ Law Number 42 Year 1999 regarding Fiduciary Guarantee.
} 
Deed signed after the signing of the Credit Agreement deed shows that the fiduciary engagement is an assesoir engagement. This means that as an agreement the assesoir fiduciary guarantee agreement has the following properties:

a. The nature of dependence on the principal agreement;

b. Its validity is solely determined by the validity of the principal agreement;

c. As a conditional agreement, it can only be executed if the conditions required in the principal agreement have been or have not been fulfilled;

Understanding, the bank in the granting of credit facilities entrust to the debtor to keep control and/ or use the object to be used in accordance with its function. During the mastering and/ or use of such objects the debtor is required to maintain the object as well as possible. In addition, the debtor is prohibited to transfer objects to other parties in any way, including a pledge back without bank approval.

In fiduciary collateral the transfer of ownership is intended solely as a guarantee for debt repayment, not to be owned by fiduciary recipients. This is at the core of the definition of fiduciary guarantees referred to in Article 1 point 1 . Even in accordance with article 33 of the Fiduciary Guaranty Act, any pledge which authorizes the fiduciary recipient to possess any object that becomes the object of fiduciary guarantee when the debtor breaches the pledge shall be void law.

The fiduciary guarantee institution as it is known to be an option for the bank because one of its advantages which has been stipulated by the fiduciary law is the inherent nature of the fiduciary object as well as by the mortgage. The droit de suite allows the fiduciary guarantee to be attached and follows the object of fiduciary collateral in the hands of whoever it belongs to, except the transfer of fiduciary objects in the form of inventory (Article 21 of the Fiduciary Guarantee Act). Another property possessed by the fiduciary guarantee agency is the nature of the predecessor (droit de preference).

According to Article 28 of the Fiduciary Guaranty Act, this principle is effective from the date of registration of the Fiduciary Guaranty Certificate at the Fiduciary Registration Office. In other words, this property is newly owned if it has been issued Fiduciary Guarantee Certificate which has executorial power. The preceding rights referred to above are intended to be the right of the fiduciary receiver to take his receivables account of the execution of fiduciary objects which are the object of fiduciary collateral. Even if the fiduciary giver is declared bankrupt or liquidated, the right to take out the receivable from the fiduciary receiver remains protected, and it is preferred because the law expressly states that fiduciary objects are not included in the fiduciary bankruptcy property.

In the provision of credit the bank will always face the risk factor of non-performing loans or bad credit. Although it has passed a fairly rigorous evaluation process, in fact non performing loans (non performing loans), still occur. Factors that cause the emergence of bad loans can be caused by internal factors bank or external factors. Internal factors can include inadequate credit analysis, poor bank owner intervention, engagement or credit documentation. While external factors may be debtor characters that are not good, changing econetic conditions, or because of natural disasters.

The Fiduciary Act does state that as long as credit is guaranteed, the right of ownership of the object to be the object of fiduciary guarantee has gone into the possession of the creditor (fiduciary receiver), so that the bank as the creditor can act to execute the fiduciary security object. is for repayment of debtor's debt. However, in practice in the field of ways of forced execution by the bank may lead to 
new legal implications if the debtor objected and complained to the bank with the articles of crime, among others, unpleasant deeds or acts of looting.

But until now there has been no debtors who use the legal channels for disagreement carried out execution under the hands. So far the debtor has only submitted his objection directly to the bank, where the bank in resolving the objection, it gives compensation time to pay off the credit installment. If within that period the debtor does not settle the obligation, the bank shall take the next step, which is to sell the collateral to settle the debtor's debt.

In the settlement of non-performing loans, the bank has a pattern of settlement that uses a special unit in charge of monitoring and collection of non-performing loans and non-performing loans. When a debtor experiences delinquent credit, the stages normally passed by the bank are by delivering orally to the debtor, followed by a written warning letter if the debtor does not complete the obligation.

However, based on the result of the research in settling the bad credit if the fiduciary is injured, the BRI Branch of Surakarta conducts the sale under the hand by requesting to the debtor in conducting its own voluntary sale of the guarantee, for subsequently the result is submitted to the bank to pay off the credit. $^{13}$

Implementation of the authority of execution under his or her possession as set forth in the Fiduciary Guaranty Act and Article 29 paragraph (1) letter C of Law Number 42 Year 1999 regarding Fiduciary Guarantee which regulates the sale under the hand. This is chosen by the bank because it is considered to be fast enough in its completion process, effective, and more efficient, compared to the settlement through the Court.

\section{Conclusion}

The process of settlement of credit is stalled if the fiduciary is unsuccessful, BRI Branch of Tangerang undertakes the sale under the hand by requesting the debtor to make its own voluntary sales voluntarily, for subsequently the result is submitted to the bank to pay off the credit. This is chosen by the bank because it is considered to be fast enough in its completion process, effective, and more efficient, compared to the settlement through the Court.

\section{Suggestion}

Banks in settlement that are stalled through the institutions of execution under the hands should follow the provisions outlined in the Fiduciary Guaranty Act in order to better coordinate with the interested parties, especially in the implementation of the sale notify the fiduciary giver of the price to be used in the sales process. This is to avoid any subsequent debtor or fiduciary complainant filing a lawsuit concerning a one-sided sale by a bank.

\footnotetext{
${ }^{13}$ Andi Mukti Santoso. (2018). Interview, Account Officer (AO) PT. Bank Rakyat Indonesria (Limited) Surakarta, on 26 June 2018.
} 


\section{References}

Habib Adjie. (2000). Deposit Rights as Land Guarantee Institution. Bandung: Mandar Maju.

Hasanuddin Rahman. (1995). Legal Aspects of Banking Credit in Indonesia. Bandung: Citra Aditya Bakti.

M. G. S Edy. (1986). Banking Credit: A Juridical Review. Yogyakarta: Liberty.

Ronny Hanitijo Soemitro. (1985). Legal Research Methodology. Jakarta: Ghalia Indonesia.

Sutrisno Hadi. (2001). National Research Methodology. Jakarta: Rineka Cipta.

Act Number 42 of 1999 regarding Fiduciary Guarantee

Act Number 14 of 1967 regarding Principles of Banking

Act Number 7 of 1992 amended by Act Number 10 of 1998 concerning Banking.

Decree of the Board of Managing Directors of Bank Indonesia Number 31/147 / DIR concerning Earning Assets Quality.

http://www.bumn-swasta.web.id/2015/12/pt-bank-rakyat-indonesia-limited-Ltd.html. accessed on July 1, 2018 at 09.28 .

\section{Copyrights}

Copyright for this article is retained by the author(s), with first publication rights granted to the journal.

This is an open-access article distributed under the terms and conditions of the Creative Commons Attribution license (http://creativecommons.org/licenses/by/4.0/). 